\title{
A Case Study on the Influence of First Language Syntax (L1) in Writing English (L2) Essays among Form Two Secondary Students
}

\author{
Amanpreet Kaur Gurdarshan Singh ${ }^{1, *}$, Mahendran Maniam ${ }^{2}$ \\ ${ }^{1}$ School of English, Faculty of Social Sciences, Quest International University Perak (QIU), Malaysia \\ ${ }^{2}$ Faculty of Languages and Communication, Universiti Pendidikan Sultan Idris (UPSI), Malaysia
}

Received March 20, 2020; Revised May 19, 2020; Accepted June 24, 2020

Copyright $(2020$ by authors, all rights reserved. Authors agree that this article remains permanently open access under the terms of the Creative Commons Attribution License 4.0 International License

\begin{abstract}
English language is one of the most important and second language after Bahasa Melayu, which is also a national language in Malaysia. Writing in English language is one of the most difficult skills for Malaysian students, especially if they do not have a good proficiency in the language. Objective of this study is to identify L2 (English) syntax transferred negatively and positively from L1 (Bahasa Melayu) in writing English (L2) essays among Form Two secondary school students. The design of this study is a qualitative which is appropriate to identify the phenomena. The data collection instruments were document analysis and interview. To execute this study, 20 writing samples were chosen from low proficiency level of students. They were instructed to write about 100 word essays on a given topic in English language. The syntax was later corroborated and compared to substantiate the theoretical arguments in the field of language transfer. From the findings, it was found that first language highly interferes in students' English language writing skills. In addition, it was found that the sample employed a translation method although they understand the significance of English language worldwide. To conclude, more actions should be taken in order to teach contrastive analysis for a better understanding of the differences in the syntax between Bahasa Melayu and English language.
\end{abstract}

Keywords Interference, Second Language Acquisition, Syntax, Transfer

\section{Introduction}

Azelin Mohamed Noor, Abdul Mutalib Embong and Osaro Aigbogun (2015) stated that other than the students' incompetence to write and speak accurately in English, they have English language phobic and this phobia extended to other subjects taught in the language. They added that parents or guardians tend not to emphasize the importance of English language to their children due to lack of interest in English language education. This lack of concern towards the English language had begun from home. Gonca (2018) mentioned that writing is a challenging task which involves many elements such as drafting ideas, organization, revising, editing content, vocabulary, mechanics and cohesion. When a writing task is given, in L2 writing, at first beginner-level L2 students are mostly inclined to use their L1 writing skills.

Bahasa Melayu inferences in English language are one of the major sources in committing syntactic errors. According to Gedion, Tati and Peter (2018) the students have directly translated the Malay words into English words which led to malformation of the sentences. First language (L1) or mother tongue has negative influences in writing English language (L2) which greatly impacts the acquisition of English language skills among secondary school students (Muriungi \& Mbui, 2013). According to Onwubiko (2012), the matter of concern now is how to raise the level of proficiency of the English language in Malaysia to a level as high if not greater than during the days of the English medium. Improving proficiency in English language only through English subjects in the school curriculum is inadequate as curriculum planners at the Education Ministry and teachers in schools have realised this fundamental matter over the years. A majority of students use Bahasa Melayu as a main medium in education in national schools. National school subjects, with the exception of the English language subject are taught in Bahasa Melayu (Onwubiko, 2012).

Students' essays are badly influenced by their L1 (Bahasa Melayu) in L2 (English) syntax writing. The students use verbs without a correct syntax due to transfer 
of L1 (Bahasa Melayu) as Bahasa Melayu has different syntax. It has been discovered that Malaysians who have a good knowledge of English frequently code-switch English into Malay, Chinese or Tamil. Musa, Koo and Azman (2012) also mentioned that there is a strong influence of the Bahasa Melayu over the learning of English among Malaysian students. Lau $\mathrm{Su}$ Kia, Xiongyong Cheng, Tan Kooi Yee, and Choo Wee Ling (2011) study has confirmed that a depressing but common phenomenon known as 'rojak language' frequently arises in Malaysia, wherein code-switching creates mixed languages. It has previously been realised that the phenomenon of code-switching is not only common in discussions among Malaysian language users but also takes place in sentences used in the entertainment news of Malaysian Chinese dailies.

Transfer from L1 to L2 was considered a form of influence of L1 habits on L2 learning (Erarslan \& Hol, 2014). Many behaviorists argue that L1 influence is a major problem for L2 learners. This situation is dominant in L2 learner's productive and receptive skills which are greatly influenced not merely by L1 patterns but also includes the factor of how great the similarities or differences between L1 and L2 languages are (Erarslan \& Ho, 2014). In fact Karim \& Nassaji (2013) study also mentioned that many researchers studied the writing strategies of L1 and L2 and found there are similarities between the two languages.

Consequently L2 writers make use of their L1 transfer and learning strategies when writing in L2. Therefore errors take place when students inappropriately transfer some features of L1 in their L2 writing (El-dali, 2012). Students who have good mastery of L2 are able to apply good transfer strategies in L1 (Abeywickrama, 2011). However, if the command of the language is inadequate, they are unable to use L1 in L2 writing effectively. This is an unconscious process and results in negative transfer (Gvarishvili, 2013). This is one issue that the researcher would like to investigate in this present study.

The study addresses the following research questions:

Which linguistic items have been transferred positively from L1 (Bahasa Melayu) in writing English (L2) essays among Form Two secondary?

Which linguistic items have been transferred negatively from L1 (Bahasa Melayu) in writing English (L2) essays among Form Two secondary?

Objective of this study is to identify L2 (English) linguistic items transferred negatively and positively from L1 (Bahasa Melayu) in writing English (L2) essays among Form Two secondary.

\section{Theoretical Framework}

Second Language Acquisition (SLA) is a process of learning any other language after the first language whether it is a second, third or fourth language. In terms of second language acquisition (SLA), students are faced with the same logical problems in the process of learning the first language. Second Language Acquisition (SLA) is the study of how students acquire a second language (L2) additionally to their first language (L1). Therefore, any language other than the first language is called a second language (SL) or it is also referred as a target language (TL). According to Hao Yu and Chi Ren (2013), L1 is the first language reaction system formed in the condition that no other language system was set up in the people's thinking system before. Any person who begins learning a new knowledge or skills has the tendency to make use of their original cognitive structure, including the L1 knowledge and abstract thinking ability learned through the L1, which constitute the original cognitive structure of SLA; this is the foundation of information processing. Watcharapunyawong and Usaha (2013) stressed that the issue is to what extent influence of L1 really affects the students especially in their L2 writing. The researcher aims to describe L2 acquisition by selecting sentence structure and identifying the underlying factors which determine the sources.

Hao Yu and Chi Ren (2013) stated that when students learning the L2, they will consciously or unconsciously tend to utilise their former information when it comes to analysing, comprehending, and comparing and thinking so that they will use the experience procured in the process of learning their L1 to direct them to master a new language. According to Sabbah (2018) "Transfer can be categorised into two types, specifically positive transfer and negative transfer. The process of using rules from L1 which facilitates or has a positive influence on learning L2 is called the positive transfer. This transfer is mainly because of similarities between L1 and L2. By comparison, negative transfer is the transfer of rules from L1 which has harmful impingement on the command of rules of L2. This is due to differences between L1 and L2". Therefore, a correct understanding of the role of L1 in the acquisition of a second language is of great significance to identify the syntax which have been transferred negatively and positively from L1 (Bahasa Melayu) to L2 (English language).

In accordance with research by Erarslan and Hol (2014), when languages have a lot of commonalities, the individual has the tendency to translate from one language to another. But then, some languages are very different from one another in many aspects and features. As claimed by Alexandra Cabrera Soalano et al, (2014), this often results in influence between the languages which causes adverse or negative effects. The issue is to what extent is second language acquisition (SLA) and first language acquisition similar or different and to what extent is the influence in students' writing specially students from national schools. Javed and Phil (2012) opine that it is therefore fundamental for language 
teachers and language students to know the structure of both second language and mother tongue because such understanding enables the language students to identify the areas of influence of mother tongue on second language.

The researcher uses Spolsky's good learners' model for this study. Spolsky's model comprises two stages of processes of language learning. Firstly, through unconscious processes of acquisition and learning, one tends to formulate aspects of transfer, simplification and generalization. On the other hand, conscious processes of acquisition and learning result in application of strategies. Both these processes have implications on the proficiency level of an individual, the types of errors made and the influence due to interlanguage (Alber, 2008).

\section{Methods}

This is a qualitative case study in one of the schools in Perak, Malaysia. Data was obtained through the use of in-depth structured interviews with eight students and document analysis. The research objective is to identify L2 (English) linguistic items transferred negatively and positively from L1 (Bahasa Melayu) in writing English language (L2) essays among Form Two secondary school students.

Twenty Form Two Malay students were selected from a national secondary school in Ipoh, Perak which comprises both genders. Eight out of these 20 students were interviewed. The sample is from the same classroom and it is adequate to provide a clear picture of the problem that is the influence of Bahasa Melayu (L1) in English language (L2) syntax in writing skills among the students. This is a nonprobability sampling which is purposive selection. According to Merriam (1998), using purposive sampling allows researchers to understand a phenomenon in depth. The subjects lived in an exclusively Malay speaking community and had learnt English language as a second language during their primary and secondary school era in a formal setting. It is a double session school and the classes are streamed according to student's accomplishment in examinations.

Data is collected from 20 Form Two students, each of whom was given an essay to write in about 100 words. The researcher read and analysed the essay written by the students to identify the errors on syntax made by the students in their essays. The results of the errors made will be tabulated and categorised according to the syntax. The essays used in the classroom had provided valuable information (provided the written work was not directly copied from the teacher's notes) pertaining to students' L1 (Bahasa Melayu) influence in the L2 writing. Therefore, the researcher only analysed written materials that were done by the students without the teacher's guidance. The tabulated results were later compared and corroborated to substantiate the theoretical arguments in the field of language transfer.

The researcher also conducted a semi-structured interview with eight Form Two students from the same classroom. Interviews are adequate to investigate the topic or phenomena not directly observable. Moreover, interviews are interactive thus the researcher can obtain more information to draw conclusions. During the interview session, both the researcher and interviewees can make clarifications about the reasons of syntax transferred negatively and positively from L1 to L2. The interview consisted of a list of questions prepared in advance to remain focused on the research and the questions were based on the research question derived earlier. Each interview lasted for about 30 minutes and it was audio taped. The researcher transcribed the interview into text data. The responses from the interview would support the findings gathered from the written essays.

\section{Results and Discussion}

The aim of this research is to identify the syntax that have been transferred negatively and positively from first language (L1), the sentences were analysed in each of the essays and noted the errors in translation. The researcher found errors of negative translations. There were no positive translations found in the essay writing practices among the students.

Negative translation is the transfer of rules from L1 which has harmful effects on students writing in L2.

From this study, it can be deduced that the L2 syntax mostly transferred negatively from L1. Linguistic items which are found in "My Family" essays were subject verb agreement, articles, possessives 's', pronouns, verb 'to be', simple present tense, simple past tense and present continuous. The following are some of the extracts from students' essays.

\section{My Family}

\section{Subject Verb Agreement}

\section{Student 1}

"In my family, I got eight members including me." (English) is written as "In my family I got eight member including me."

Bahasa Melayu: Di dalam keluarga saya, saya mempunyai lapan orang ahli keluarga termasuk diri saya.

\section{Student 4}

"I have two sisters." (English) is written as "I have two sister."

Bahasa Melayu:Saya mempunyai dua orang adik perempuan. 


\section{Articles}

Students 1

"And then, I got a sister." (English) is written as "And then, I got sister."

Bahasa Melayu: Dan selepas itu, saya dapat seorang kakak.

"I also have a little brother and a little sister." (English) is written as "I also got my little brother and little sister."

Bahasa Melayu: Saya juga mempunyai adik lelaki kecil dan adik perempuan kecil.

Student 14

"I'm the only child." (English) is written as "I'm an only child."

Bahasa Melayu: Saya anak tunggal.

\section{Possessives ' $s$ '}

Students 2

"My eldest sister's name is Nur Ain." (English) is written as "My eldest sister name is Nur Ain."

Bahasa Melayu: Nama kakak sulung saya ialah Nur Ain.

"My father's age is 48 years old." (English) is written as "My father age is 48 years old."

Bahasa Melayu: Bapa saya berumur 48 tahun.

Student 4

"My father's name is Muhamad Nasir bin Johari." (English) is written as "My father name is Muhamad Nasir Bin Johari."

Bahasa Melayu: Nama bapa saya ialah Muhamad Nasir bin Johari.

\section{Student 7}

"My mother's name is Narina binti Yusof and my father's name is Suhaimi Bin Mustafa." (English) is written as "My mother name is Narina binti Yusof and my father is Suhaimi Bin Mustafa."

Bahasa Melayu: Nama ibu saya ialah Narina binti Yusof dan nama bapa saya ialah Suhaimi Bin Mustafa.

\section{Pronouns}

Student 2

"His name is Muhammad Syahrin Nazrin." (English) is written as "He name is Muhammad Syahrin Nazrin."

Bahasa Melayu: Nama dia ialah Muhammad Syahrin Nazrin.

\section{Student 3}

"My father's occupation is a navy." (English) is written as "My father occupation is a navy."

Bahasa Melayu: Ayah saya seorang tentera laut.

\section{Student 8}

"My father's name is Kamaruddin Bin Kulop Mat Isa." (English) is written as "My father name is Kamaruddin Bin Kulop Mat Isa."

Bahasa Melayu: Nama bapa saya adalah Kamaruddin Bin Kulop Mat Isa.

\section{Student 17}

"He was so fierce and funny." (English) is written as "His was so fierce and so funny."

Bahasa Melayu: Dia begitu kejam dan sangat lucu.

\section{Verb 'to be'}

\section{Student 3}

"I am elder than one of my siblings." (English) is written as "I is elder one sibling include me."

Bahasa Melayu: Saya tua daripada seorang adik beradik saya.

\section{Student 4}

"My name is Anis Batrisyia." (English) is written as "My name Anis Batrisyia."

Bahasa Melayu: Nama saya Anis Batrisyia.

"My father is so funny and cute." (English) is written as "My father so funny and cute."

Bahasa Melayu: Ayah saya sangat lucu dan comel.

"She is 50 years old." (English) is written as "She 50 years old."

Bahasa Melayu: Dia berumur 50 tahun.

\section{Student 5}

"My parents are very kind and good people." (English) is written as "My parents is very kind and good person."

Bahasa Melayu: Ibu bapa saya sangat murah hati and baik-baik orang.

\section{Simple Present Tense}

Student 5

"My mother works as a clerk." (English) is written as "My mother work as clerk."

Bahasa Melayu: Ibu saya bekerja sebagai kerani.

\section{Student 13}

"He works as an online promoter." (English) is written as "He work as a online promoter."

Bahasa Melayu: Dia bekerja sebagai promoter dalam talian.

\section{Student 19}

"My mother works at Aeon Mall." (English) is written as "My mother work at Aeon Mall."

Bahasa Melayu: Ibu saya bekerja di Aeon Mall.

Student 20 
"However, he loves me so much as his daughter." (English) is written as "Even though, he is very love at us as his daughter."

Bahasa Melayu: Walaubagaimanapun dia sangat sayangi saya sebagai anak perempuannya.

\section{Simple Past Tense}

\section{Student 8}

"Last time, my father worked as a soldier." (English) is written as "My father work last time is soldier."

Bahasa Melayu: Masa dulu ayah saya berkerja sebagai seorang askar.

\section{Present Continuous}

Student 1

"She is not working but she helps my family with business until success." (English) is written as "She not working but she help my family with do business until success."

Bahasa Melayu: Dia tidak bekerja tetapi dia membantu keluarga saya menjalankan perniagaan sehingga berjaya.

\section{Student 15}

"Now, he is waiting to pursue his studies." (English) is written as "Now, He waiting to pursue a study."

Bahasa Melayu: Sekarang dia menunggu untuk melanjutkan pelajarannya.

\section{Responses from Interview Session}

This interview was carried out with eight students from the same classroom. It was carried after the completion of the essays. The researcher recorded the interview session and transcribed it. The focus was on the students themselves and each of the questions were examined from their perspectives.

The researcher asked the students if they think Bahasa Melayu helps them when writing in English language, table 1 demonstrates that seven students $(7 / 8,87.5 \%)$ responded yes as it will help them in their writing. For example reasons given by students were "I don't remember the tenses ... I will write in Malay and I will translate it.", "I can translate it to English.", "Because Bahasa Melayu is easy", "because can translate." "Easy to make sentences".

Table 1. Bahasa Melayu Assists in English Language Writing Skills

\begin{tabular}{|c|c|c|c|c|}
\hline & $\begin{array}{c}\text { Frequenc } \\
\mathrm{y}\end{array}$ & Percent & $\begin{array}{c}\text { Valid } \\
\text { Percent }\end{array}$ & $\begin{array}{c}\text { Cumulative } \\
\text { Percent }\end{array}$ \\
\hline $\begin{array}{c}\text { Valid } \\
\text { No }\end{array}$ & 1 & 12.5 & 12.5 & 12.5 \\
\hline Yes & 7 & 87.5 & 87.5 & 100 \\
\hline Total & 8 & 100 & 100 & \\
\hline Mean & 0.88 & & & \\
\hline $\begin{array}{c}\text { Std. } \\
\text { Deviation }\end{array}$ & 0.354 & & & \\
\hline
\end{tabular}

"Do you think in Bahasa Melayu before you write in English?" the researcher checked with the students and found eight students who think in Bahasa Melayu before writing in English language. Five of the students mentioned that they do write in Bahasa Melayu on a piece of paper separately before writing in English language.

From the findings, it is clear that the students involved in this study use their knowledge of first language (L1) in writing of English language (L2). As compared to the English language, students are more familiar with it as it is their mother tongue. This supports Watcharapunyawong and Usaha (2013) study that stresses the issue of what extent influence of L1 really affects the students especially in their L2 writing. This supports Muriungi \& Mbui (2013) who claimed that the mother tongue has a strong influence over writing in English language among the secondary school students. This similarly coincides to Sabbah (2018) and Alexandra Cabrera Soalano et al, (2014), that rules from L1 which has negative impact on the command of rules of L2. On the other hand, those students who are incompetent in English language (L2) seem to use to Bahasa Melayu (L1) rules in their writings.

The findings also showed all the students have problems distinguishing the right syntax. This reflects on Javed and Phil (2012) that it is crucial for language teachers and language students know the structure of both second language and first language because such awareness enables the language students to identify the areas of influence of first language on second language. This may seem parallel with Hao Yu and Chi Ren (2013) statement that students learn the L2 will consciously or unconsciously apply their previous information to gain knowledge. This is where the L2 students tend to process information from their L1 to master their L2. During the interview session with students most of them agreed that Bahasa Melayu helps them in writing English essays. This supports Musa, Koo and Azman (2012) where they mentioned that Bahasa Melayu strongly influences the learning of English among students. This relates to the claims by Gvarishvili (2013) and Gedion, Tati and Peter (2018) that it is an unconscious process where students tend to use translation methods to write in L2 which results in negative transfer. This is parallel to Darmi and Albion (2013) that standard of English is declining among most Malaysian students due to the change of medium instruction from English to Bahasa Melayu. It is also found that students prefer to refer to their teachers for any difficulties in learning English. This supports Muriungi and Mbui (2013) that schools play a major role to motivate the students in a number of ways such as providing essential resources in facilitating learning of English.

As a note, the majority of the students seem to have very little knowledge of English language as they have problems in writing using the correct English language syntax. This led them to use translation of what they are 
supposed to be made aware of in schools of their mother tongue interferences in their second language writing.

\section{Conclusions}

This study has identified eights types of syntactic errors which the students wrote in the writing practice. It is found that the students had difficulties to write correct sentence structures. The syntactic errors found in this study are subject verb agreement, articles, possessives 's', pronouns, verb 'to be', simple present tense, simple past tense and present continuous. Furthermore, the study has demonstrated that students still rely on their L1 (Bahasa Melayu) in their writing skills. Students tend to use their L1 rules (Bahasa Melayu) to translate their sentence into L2 (English language) unconsciously. Students also stressed during the interview session that they use translation methods to write in English language (L2) as it guides them to complete the writing task. It is distressed to find this occurrence facing these students who are still not aware of the usage of singular and plural nouns. They have difficulties constructing simple sentences in their L2 writings. Additionally, this study also revealed that exposure towards the English language from Year One in Malaysian education system still does not assure the students to be able to master the language.

\section{Recommendation}

This finding strongly recommends that ESL educators spend more of their class time focusing on the error prone areas. A suggestion for English language teachers in Malaysia should make a determination to show the differences between these two languages which are Bahasa Melayu and English language in terms of the frequent errors made consciously or unconsciously by the students. Besides, this can be done by emphasizing English language syntax in detail rather than in a few lessons. One of the important strategies is a teacher's role to motivate their students to work harder and guide them to improve English language by advising them the effects of using direct translation from their first language. Besides, using online platforms is also useful to enhance students' interest in acquiring a second language such as kahoot, google classroom and jamboard. Future researchers may integrate observations in the classroom and conduct interviews with the English language teachers who are teaching the beginner level of secondary school students to identify the successful or unsuccessful strategies and methods which are applied by them. Furthermore, teachers can try using a grammar translation method for the beginner level of students. Grammar translation method uses first language (L1) to teach second language (L2). Abdul Bari Khan Abdul Bari Khan and Hafiza Sana Mansoor (2016) highlighted that in grammar translation method students can comprehend the message through reading text and can produce grammatically correct sentences if they are aware of grammatical rules of first language and second language. Moreover, this will assist the future researchers to examine grammar translation method to teach students who have low proficiency in English language. In addition, the paper should also look into interviewing the students on learning strategies which best for them to acquire the syntactical knowledge of English language. This can lead to a more nuanced and in-depth insight on designing curriculum syllabus for beginner level of secondary school students.

\section{Limitation}

Limitation of this research is it focuses only on secondary school students from one particular school in Ipoh, Perak. Therefore, more research is needed to survey the errors in writing made by secondary and primary students of multiracial in Malaysia to identify if Bahasa Melayu which is also the national language of the country has a negative impact towards mastering English language.

\section{REFERENCES}

[1] Abdul Bari Khan, Hafiza Sana Mansoor (2016). The Effectiveness of Grammar Translation Method in Teaching and Learning of English Language at Intermediate Level. International Journal of Institutional \& Industrial Research, 22-25 1(1)

[2] Abeywickrama, R. (2011). An Analysis of Errors in English Writing of Sinhala Speaking Undergraduates. Sabaragamuwa University Journal, 9(1), 97-114. http://doi.org/10.4038/suslj.v9il.3737

[3] Abler, W.L. (2008). The nature of language. Science Progress, 89 PART 1, 81-70. http://doi.org/10.3184/003885 008783208382

[4] Alexandra Cabrera Solano, P., Fernando Gonzalez Torres, P., Augusto Ochoa Cueva, C., Lucia Quinonez Beltran, A., Mercedes Castillo Cuesta, L., Mercedes Solano Jaramillo, L., Olivia Arias Cordova, M. (2014). Spanish Influence in EFL Writing Skills: A Case of Ecuadorian Senior High Schools. English Language Teaching, 7(7), 40-48. http://doi.org/10.5539/elt.v7n7p40

[5] Azelin Mohamed Noor, Abdul Mutalib Embong and Osaro Aigbogun (2015). Using L1 in L2 Classrooms: A Case Study among Secondary School Students of Mixed English Language Proficiencies. International Journal of Arts \& Sciences, 08(02), 75-88.

[6] Darmi, R., \& Albion, P. (2013). English Language in Malaysian Education System: Its Existence and Implication. Research Gate, 175-183.

[7] Erarslan, A., \& Hol, D. (2014). Language Influence on 
English: Transfer on the Vocabulary, Syntax and Preposition Use of Freshmen Turkish EFL Learners. ELTA Journal, 2(2), 4-22.

[8] Gedion, Tati and Peter (2018). A Syntactic Errors Analysis in the Malaysian ESL Learners'. Journal of Applied Linguistics and Language Research, 8(3), 98-104.

[9] Gonca, A. (2018). Do L2 writing courses affect the improvement of L1 writing skills via skills transfer from L2 to L1? Academic Journal, 11(10), 987-997.

[10] Gvarishvili, Z. (2013). Influence of L1 Prepositional Knowledge in Acquring of Prepositional Usage in English. Procedia- Social and Behavioral Sciences, 70, 1585- 1573. http://doi.org/10.1018/j.sbspro.2013.01.220

[11] Hao Yu \& Chi Ren (2013). The Positive Role of L1 in the Acquisition of a Second Language. Studies in Literature and Language, 2 (7), 45-48.

[12] Javed, M., \& Phil, M. (2012). Strength for Today and Bright Hope for Tomorrow Etymological Analysis of the English Language Words. Language in India, 9 (12), 580-592.

[13] Karim, K., \& Nassaji, H. (2013). First language transfer in second language writing: An examination of current research. Iranian Journal of Language Teaching Research, 1(1), 117- 134 .

[14] Lau, S.K., Cheng, X., Tan K.Yee., \& Choo W. L. (2011).
Code-switching of English in the Entertainment News of Chinese Newspapers in Malaysia. International Journal of English Linguistics, 1(1), 3-14.

[15] Merriam, S.B. (1998): Qualitative Research and Case Studies Applications in Education. San Francisco: Jossey-Bass Publications.

[16] Muriungi, P. K., \& Mbui, M. K. (2013). The influence of mother-tongue maintenance on acquisition of English language skills among day secondary school students in Imenti South District, Kenya. International Journal of Linguistics, 5(1), 298-305.

[17] Musa, N.C., Lie, K.Y., \& Azman, H. (2012). Exploring English Language Learning and Teaching in Malaysia. Journal of Language Studies, 12(1), 35-51. http://doi.org/10.1111/j.1944.9720.2007.tb03201.x

[18] Sabbah, S. (2018). Negative Transfer: Arabic Language Influence to English Learning. Arab World English Journal (AWEJ) Special Issue on Translation, 4, 289-288. http://dx.doi.org/10.2139/ssrn.2844015

[19] Onwubiko, E. C. (2012). Unifying Role of Malay Language in a Multilingual Nation: A Case of Malaysia. US-China Foreign Language, 7(10), 1349-1354.

[20] Watcharapunyawong, S., and Usaha, S. (2013). Thai EFL students' writing errors in different text types: The interference of the first language. English Language Teaching, 8(1), 87-78. http://doi.org/10.5539/elt.v8n1p87 